\title{
Synthesis, Characterization, and Antibacterial Activity of N-substituted Quaternized Chitosan and Its Cellulose- based Composite Film
}

\begin{abstract}
Qiyuan Chen, ${ }^{\mathrm{a}}$ Shengling Xiao, ${ }^{\mathrm{a}, *}$ Sheldon Q. Shi, ${ }^{\mathrm{b}}$ and Liping Cai ${ }^{\mathrm{b}}$
A water and organic soluble $\mathrm{N}$-benzyl-N,N-diethyl quaternized chitosan (NSQC) material was synthesized using chitosan, benzaldehyde, and bromoethane. Amino groups on chitosan reacted with benzaldehyde to form a Schiff base intermediate. Quaternized chitosan was obtained by reacting the Schiff base with bromoethane. The quaternized chitosan was dissolved in an organic solution with dissolved cellulose and cast to prepare quaternized chitosan/cellulose (QCC) film. The molecular structure, morphology, tensile strength, thermal stability, and antibacterial activity effects of NSQC-treated cellulose film were studied in detail. The results showed that the NSQC product exhibited superior solubility in deionized water and dimethylacetamide. The addition of NSQC as a reinforcing agent in QCC film enhanced the interlinking of fibers and slowed down the rate of cellulose pyrolysis, which improved the tensile properties and thermal stability of the cellulose film. The minimum inhibitory concentration (MIC) and minimum bactericidal concentration (MBC) values of NSQC showed that it had good antibacterial activity against Staphylococcus aureus and Escherichia coli. The QCC film also showed contact sterilization ability with regards to two kinds of bacteria, which suggested that QCC film has the potential for applications in food packaging and bacterial barriers.
\end{abstract}

Keywords: Chitosan; Quaternized chitosan; Cellulose films; Antibacterial activity

Contact information: a: College of Engineering and Technology, Northeast Forestry University, 26 Hexing Road, Harbin 150040, China; b: Department of Mechanical and Energy Engineering, University of North Texas, Denton, TX 76203, USA; *Corresponding author: shenglingxiao@126.com

\section{INTRODUCTION}

As a product of deacetylation of chitin, chitosan, $\operatorname{poly}(\beta-(1 \rightarrow 4)-\mathrm{N}$-acetyl-Dglucosamine), is a natural, weakly alkaline polysaccharide with a structure similar to cellulose (Rinaudo 2006). Studies have shown that protonated ammonium $-\mathrm{NH}_{3}{ }^{+}$in chitosan molecules is strongly positively charged under acidic conditions and could adsorb negatively charged surface bacteria and destroy their cell wall composition, causing bacterial death (Chang et al. 2015, 2019). Thus, chitosan has displayed a broad spectrum of antibacterial activity against a wide range of microorganisms, including bacteria, yeasts, and fungi (Kumar et al. 2016; Crini 2019). Because of the complex hydrogen-bonded semicrystalline structure within the chains, the pKa value of chitosan is approximately 6.5 , making it insoluble in water and common organic solvents; it only becomes soluble in an acidic medium with $\mathrm{pH}<6.5$ due to the protonation of amine groups (Liu et al. 2006; Zargar et al. 2015; Chen et al. 2016). Therefore, poor solubility of chitosan restricts its antibacterial applications to some extent. The chitosan molecular structural unit contains a primary amino group $\left(-\mathrm{NH}_{2}\right)$ and two hydroxyl groups $(-\mathrm{OH})$, making it easy for it to be 
chemically modified to obtain functionalized chitosan derivatives with improved biological properties and water solubility (Chen et al. 2016; Zou et al. 2016; Jelkmann et al. 2018). Thus, the development of functionalized chitosan quaternary ammonium salts with higher positive charge density has become a popular topic of research (Fan et al. 2018).

A common method of quaternization treatment of chitosan involves alkylation modification of $-\mathrm{NH}_{2}$ and adding quaternization reagents, continuously quaternizing the amino groups (Wei et al. 2019). Other methods include grafting an ammonium salt directly on the $-\mathrm{NH}_{2}$ or $-\mathrm{OH}$ at the $\mathrm{C} 6$ position (Xu et al. 2011; Wang et al. 2016) or esterifying the -OH and then grafting the salt (Guo et al. 2007; Sahariah and Másson 2017). Glycidyl trimethylammonium chloride (GTMAC) was used to directly graft and replace the H of $\mathrm{NH}_{2}$ and $-\mathrm{OH}$ at the $\mathrm{C} 6$ position to obtain O-substituted, $\mathrm{N}$-substituted quaternized chitosan (HTCC) that displayed superior water solubility and antibacterial activity (Wei et al. 2018; Wang et al. 2019). The alkylation of $-\mathrm{NH}_{2}$ is an early method for chitosan quaternization (Martins et al. 2014). Chitosan can be directly reacted with quaternizing agents $\mathrm{CH}_{3} \mathrm{I}$ to obtain N,N,N-trimethyl chitosan (TMC) (Sadeghi et al. 2008). Recent studies have focused on grafting functional groups on $-\mathrm{NH}_{2}$ to give the products special properties (e.g., antibacterial, dye adsorption, and targeted catalysis) (Lee et al. 2015; Li et al. 2016; Ghazaie et al. 2019). The antibacterial ability of chitosan enhanced by grafting a quaternary ammonium salt on the molecular structure is attributed to its positive charge density, which is enhanced by converting $-\mathrm{NH}_{2}$ to $-\mathrm{NH}_{3}{ }^{+}$(Guo et al. 2007). It was found that the length and type of the alkyl group grafted to the chitosan affects the antibacterial activity of quaternized chitosan, and that grafting a benzyl group leads to better results than grafting a methyl group (Jia et al.2001). Therefore, the use of aldehydes containing benzylic groups is preferred for the preparation of highly antibacterial activity chitosan quaternary ammonium salts.

Cellulose-based materials have been widely used in various fields due to their low price, good regeneration ability, and high strength (Thakur and Voicu 2016). The antibacterial film that is fabricated by blending chitosan with cellulose has wide application prospects in the fields of food packaging and bacterial barriers (Abdul Khalid et al. 2016; Gan and Chow 2018; Niu et al. 2018). This study focused on the synthesis of N-substituted quaternized chitosan and the fabrication of its quaternized chitosan/cellulose composite film. The chemical structure of the synthesized product was characterized by Fouriertransform spectroscopy (FT-IR) and nuclear magnetic resonance spectroscopy (NMR). The surface morphology, tensile strength, and thermal stability of the composite film were evaluated by scanning electron microscopy (SEM), thermogravimetric analysis (TGA), and tensile tests. The minimum inhibitory concentration (MIC), minimum bactericidal concentration (MBC) value, and contact antibacterial ability of the fabricated films against Escherichia coli and Staphylococcus aureus were investigated to provide further research with theoretical supports.

\section{EXPERIMENTAL}

\section{Materials}

Cellulose $(\alpha$-cellulose $>80 \%)$ was experimentally self-made via the preparation method described in previous experiments (Chen et al. 2018). Chitosan (with a $>95 \%$ degree of deacetylation), benzaldehyde, and bromoethane were purchased from Shanghai 
Aladdin Bio-Chemical Technology Co., Ltd. (Shanghai, China). All other solvents and agents were of analytical grade. S. aureus (ATCC 6538) and E. coli (ATCC 25922) were obtained from China General Microbiological Culture Collection Center (Beijing, China).

\section{Synthesis of $N$-substituted quaternized chitosan}

Approximately $2 \mathrm{~g}$ of accurately weighed chitosan was dissolved in $100 \mathrm{~mL}$ of $1 \%$ (wt\%) acetic acid under magnetic stirring at $35{ }^{\circ} \mathrm{C}$ to obtain a chitosan solution. Approximately $14.0 \mathrm{~mL}$ of benzaldehyde was added into the solution and stirred for $5 \mathrm{~h}$ at room temperature. Then, the $\mathrm{pH}$ of the solution was adjusted to $4.5 \mathrm{using} 1.0 \mathrm{~mol} / \mathrm{L}$ sodium hydroxide. Approximately $30.0 \mathrm{~mL}$ of sodium borohydride $(0.01 \mathrm{~mol} / \mathrm{L})$ was added to the solution before the solution was stirred for $12 \mathrm{~h}$ at room temperature. The $\mathrm{pH}$ of the solution was adjusted to 10 after stirring, and N-benzyl chitosan derivatives were obtained by washing the white precipitate of solution with distilled water to a neutral $\mathrm{pH}$ and drying the solution at $40{ }^{\circ} \mathrm{C}$.

Approximately $1.0 \mathrm{~g}$ of N-benzyl chitosan derivatives was dissolved into $50.0 \mathrm{~mL}$ of $\mathrm{N}$-methyl pyrrolidone and stirred for $12 \mathrm{~h}$ at $50{ }^{\circ} \mathrm{C}$. Approximately $5.0 \mathrm{~mL}$ of sodium hydroxide $(3.0 \mathrm{~mol} / \mathrm{L}), 1.030 \mathrm{~g}$ of sodium bromide, and $5.4 \mathrm{~g}$ of bromoethane were added to the solution, and continuously stirred for $12 \mathrm{~h}$ at $50{ }^{\circ} \mathrm{C}$. After the reaction, the solution was added dropwise to acetone, and N-benzyl-N,N-diethyl quaternized chitosan (NSQC) was obtained by filtering the white precipitate and drying the solution at $40{ }^{\circ} \mathrm{C}$.

\section{Preparation of cellulose films}

The $\mathrm{LiCl}$ was added to a dimethylacetamide (DMAc) reagent at a weight ratio of 4:45 (w/w) to prepare the $\mathrm{LiCl} / \mathrm{DMAc}$ solution. Cellulose was dissolved in a $\mathrm{LiCl} / \mathrm{DMAc}$ solution with a weight ratio of 1:49 (w/w). The mixture was then heated and stirred in an oil bath at $105{ }^{\circ} \mathrm{C}$ for $2 \mathrm{~h}$. The solution was cooled to room temperature and remained for $12 \mathrm{~h}$ to eliminate bubbles.

The NSQC was added to the cellulose LiCl/DMAc solution with different mass ratios of chitosan to cellulose $(0: 100,1: 100,2: 100,4: 100,8: 100$, and 16:100). The solutions were then heated and stirred in an oil bath at $70{ }^{\circ} \mathrm{C}$ for $4 \mathrm{~h}$. The mixtures of solutions were uniformly cast onto glass plates to pre-solidify them in air. The solidified gels were immersed in the distilled water bath at $20{ }^{\circ} \mathrm{C}$ for $4 \mathrm{~h}$ to remove the residual solvent. The wet cellulose hydrogel samples were dried at room temperature to obtain uniform films. The films obtained by different mass ratios of chitosan to cellulose (0:100, 1:100, 2:100, 4:100, 8:100, and 16:100) were labeled as RC, QCC1, QCC2, QCC3, QCC4, and QCC5 films, respectively. The average thickness of the films was $20 \mu \mathrm{m}$ to $40 \mu \mathrm{m}$.

\section{Methods}

NSQC chemical structure

The yield of NSQC was estimated using Eq. 1,

$$
y=\frac{w_{2} \times 161.2}{w_{1} \times 388} \times 100 \%
$$

where $w_{1}$ is the dry weight of the chitosan $(\mathrm{g})$ and $w_{2}$ is the dry weight (g) of the NSQC product. The constant 161.2 represents the molar mass of chitosan and the constant 388 represents the molar mass of NSQC.

The degree of substitution (DS) of NSQC was calculated with the Mohr method by titration of $\mathrm{Br}^{-}$concentrate. The specific steps were as follows: $1 \mathrm{~g}$ of dry NSQC was 
dissolved in $100 \mathrm{~mL}$ of deionized water and the $\mathrm{pH}$ of the solution was adjusted to 9 , and then $2 \mathrm{~mL}$ of $8 \%$ potassium dichromate solution was added as the acid-base indicator. Approximately $0.1 \mathrm{~mol} / \mathrm{L}$ of silver nitrate standard solution was used to titrate the solution. The DS of NSQC was estimated using Eq. 2,

$$
D S=\frac{v \times c \times 10^{-3}}{v \times c \times 10^{-3}+\left(m-v \times c \times 10^{-3} \times 388\right) / 161.2} \times 100 \%
$$

where $v$ is the titrant consumption (mL) of silver nitrate standard solution, $m$ is the dry weight $(\mathrm{g})$ of the NSQC product, and $c$ is the concentration $(\mathrm{mol} / \mathrm{L})$ of silver nitrate standard solution. The constant 161.2 represents the molar mass of chitosan and the constant 388 represents the molar mass of NSQC.

The FT-IR spectra of chitosan, N-benzyl chitosan derivatives, and NSQC were collected on a Frontier instrument (PerkinElmer, Foster, CA, USA) in the range from 600 $\mathrm{cm}^{-1}$ to $4,000 \mathrm{~cm}^{-1}$ with a resolution of $4 \mathrm{~cm}^{-1}$.

${ }^{1} \mathrm{H}$ Nuclear magnetic resonance $\left({ }^{1} \mathrm{H}\right.$ NMR) and ${ }^{13} \mathrm{C}$ nuclear magnetic resonance $\left({ }^{13} \mathrm{C}\right.$ NMR) spectra were all recorded on NSQC dissolved in $\mathrm{D}_{2} \mathrm{O}$ with a Bruker AVANCE III HD Spectrometer (500 MHz; Bruker Corporation, Beijing, China) at $25^{\circ} \mathrm{C}$.

\section{Films morphology, thermal stability, and mechanical properties}

The surface and cross-section micromorphology of RC and QCC4 films were observed via SEM (Quanta200; FEI Company, Golden, CO, USA) at low acceleration voltages of $12.5 \mathrm{kV}$. The films were coated with gold by a vacuum sputter coater (SCD 005; Bal-tec ${ }^{\mathrm{TM}}$, Los Angeles, CA, USA) before observation. The surface element content of the films was determined by an EDAX detector of the SEM.

The thermal stability of RC and QCC4 films were measured by TGA using a TG analyzer (SDT Q600; TA instruments, New Castle, DE, USA) at a heating rate of 20 ${ }^{\circ} \mathrm{C} / \mathrm{min}$ from $50{ }^{\circ} \mathrm{C}$ to $750{ }^{\circ} \mathrm{C}$ under a high purity air atmosphere.

According to the ISO 1924-2 (2008) standard, mechanical property tests were conducted at room temperature using a universal testing machine (IMT-202F; International Material Tester Co., Ltd., Dongguan, China). The cross-head speed was $10 \mathrm{~mm} / \mathrm{min}$. The dimensions of the test films were $100 \mathrm{~mm} \times 10 \mathrm{~mm} \times 0.02 \mathrm{~mm}$ to $0.04 \mathrm{~mm}$. The initial separation of the grips was $50 \mathrm{~mm}$.

\section{NSQC and films antibacterial activity}

The antibacterial activity of NSQC against E. coli and $S$. aureus were determined by MIC and MBC values. Both MIC and MBC were measured according to the Clinical and Laboratory Standards Institute standards CLSI M07-A10 (2015) and CLSI M26-A (1999).

The antibacterial activity of composite films against two kinds of bacteria were qualitatively tested by the film inhibition zone. Approximately $0.5 \mathrm{~mL}$ of $10^{6} \mathrm{CFU} / \mathrm{mL}$ fresh bacterial bacteria solution were evenly coated on the nutrient agar (NA) plate in the clean bench. Then, $13 \mathrm{~mm}$ diameter of round punched RC to QCC4 films were attached to the surface of the plate. The plates were incubated at $37^{\circ} \mathrm{C}$ for $48 \mathrm{~h}$, and the zone of inhibition diameter of the films was measured with a vernier caliper.

The contact sterilization ability of modified cellulose film against the two types of bacteria was determined according to the ISO 22196 (2011) standard. Approximately $10^{6}$ $\mathrm{CFU} / \mathrm{mL}$ of fresh bacterial bacteria solution was coated on the surface of the blank plate, (RC and QCC4 films), and covered with polypropylene films. After incubation at $37{ }^{\circ} \mathrm{C}$ 
for $24 \mathrm{~h}$, the plate, film, and cover film were washed carefully using a nutrient broth $(\mathrm{NB}) / \mathrm{H}_{2} \mathrm{O}$ eluent with a volume ratio of $1: 100(\mathrm{v} / \mathrm{v})$. Approximately $0.5 \mathrm{~mL}$ of the eluate was then coated on the NA plate and incubated for $48 \mathrm{~h}$ at $37{ }^{\circ} \mathrm{C}$ with a humidity of $>95 \%$ before the growth of bacteria was observed.

\section{RESULTS AND DISCUSSION}

\section{Analysis of NSQC Chemical Structure}

The synthetic route of NSQC is shown in Scheme 1. Chitosan contains a free $-\mathrm{NH}_{2}$ group, which can combine with the $\mathrm{H}^{+}$of dilute acid to form an amine salt and dissolve in dilute acid. The $-\mathrm{NH}_{2}$ dissolved in $1 \%$ acetic acid was condensed with the aldehyde group in benzaldehyde to produce a chitosan-Schiff base intermediate. Then, the N-benzyl chitosan derivatives were obtained by reduction with sodium borohydride in a weakly acidic environment. The formation of quaternary ammonium salt was completed via a substitution reaction of chitosan amine protons with ethyl groups of bromoethane, forming NSQC. The NSQC yield was $64.7 \%$, and it had presentable water and organic solubility, and could be directly dissolved to $1 / 100 \mathrm{~g}$ in deionized water and DMAc. The DS degree of NSQC, calculated by the Mohr method, was $91.7 \%$, which indicated that a small amount of chitosan and derivatives were not quaternized during the reaction.

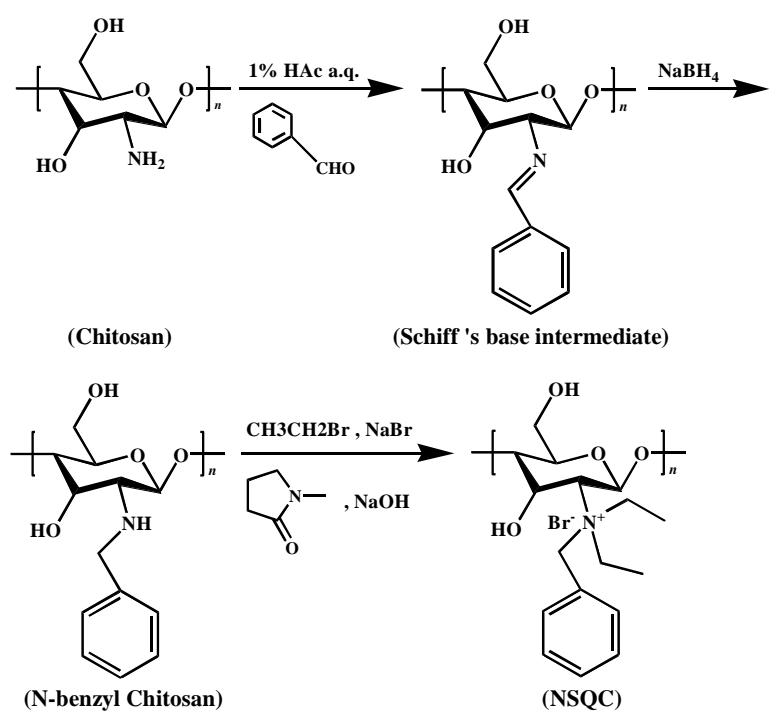

Scheme 1. Synthetic route of NSQC

Changes in the chemical composition and chemical structure of chitosan to NSQC were illustrated by FT-IR, as shown in Fig. 1. The absorption peaks around $3000 \mathrm{~cm}^{-1}$ and $1159 \mathrm{~cm}^{-1}$ were the $\mathrm{C}-\mathrm{H}$ and $\mathrm{C}-\mathrm{O}$ stretching vibration peaks of chitosan, respectively, which were apparent in each spectrum of the sample. The peaks at $756 \mathrm{~cm}^{-1}$ and $695 \mathrm{~cm}^{-1}$ represented monosubstituted benzene characteristic bands of the benzyl structure grafted on chitosan, which were not present in the spectrum of chitosan. The absorption peaks of $1643 \mathrm{~cm}^{-1}$ and $1581 \mathrm{~cm}^{-1}$ belonged to $\mathrm{C}=\mathrm{N}$ symmetry and asymmetric vibration peaks, demonstrating that the Schiff base structure was successfully synthesized. The spectrum of NSQC changed noticeably after quaternization. Many new peaks appeared around 1500 $\mathrm{cm}^{-1}$, which may be the characteristic absorption bands of NSQC. 


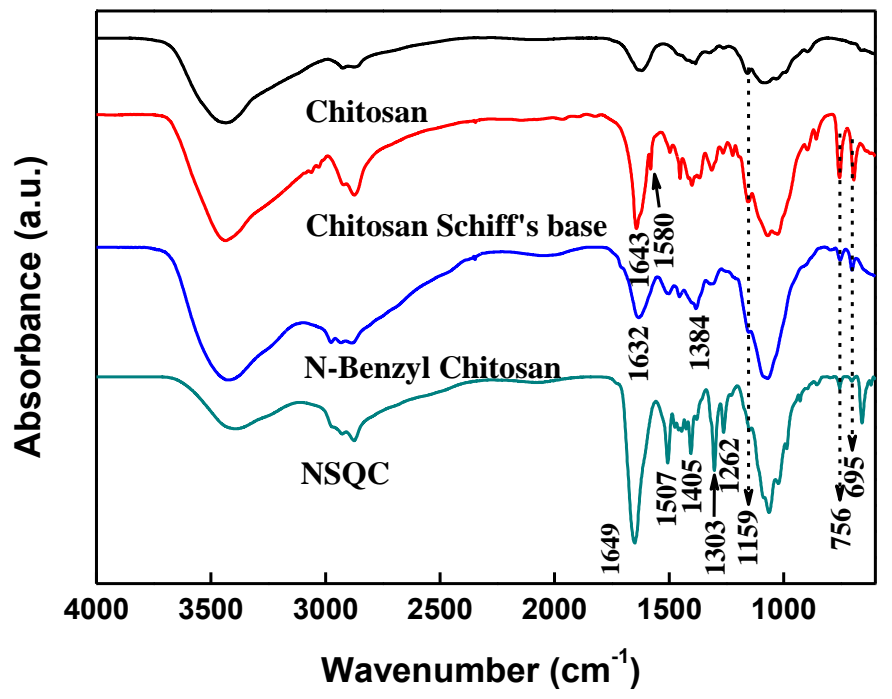

Fig. 1. FTIR spectra of chitosan and chitosan derivatives

The NMR spectra were applied to further confirm the chemical structure of NSQC. The ${ }^{1} \mathrm{H}$ and ${ }^{13} \mathrm{C}$ NMR spectra of NSQC and the peaks attributions are shown in Fig. 2.

(b)

(a)

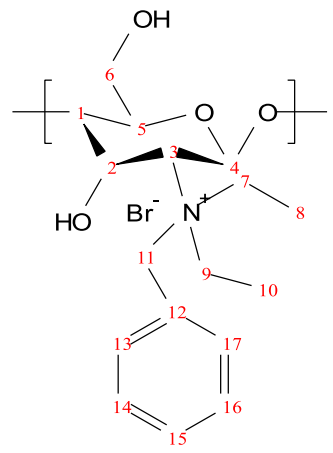

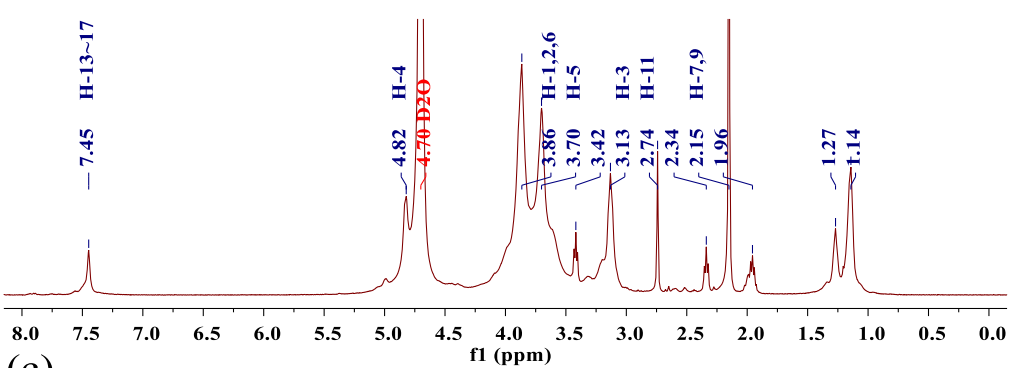

(c)

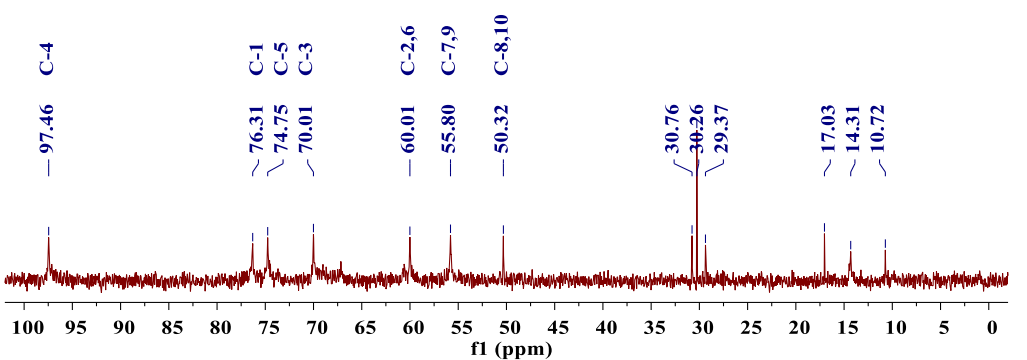

Fig. 2. NMR spectra of NSQC: (a) Peaks attributed to the NSQC NMR spectra; (b) ${ }^{1} \mathrm{H}$ NMR spectra of NSQC; and (c) ${ }^{13} \mathrm{C}$ NMR spectra of NSQC

The absorption peaks at $4.82 \mathrm{ppm}, 3.86 \mathrm{ppm}, 3.70 \mathrm{ppm}$, and $3.13 \mathrm{ppm}\left({ }^{1} \mathrm{H}\right)$ were assigned to the chemical shifts $(\delta)$ of the $\mathrm{H}-4, \mathrm{H}-1, \mathrm{H}-2$, and $\mathrm{H}-6, \mathrm{H}-5$, and $\mathrm{H}-3$ positions of chitosan structure. The peak at $7.45 \mathrm{ppm}\left({ }^{1} \mathrm{H}\right)$ was the characteristic peak of the benzene ring, indicating that the benzyl structure was successfully grafted on the amino groups, which was confirmed by the results of FTIR. The strong peak at $2.74 \mathrm{ppm}$ and $2.15 \mathrm{ppm}$ $\left({ }^{1} \mathrm{H}\right)$ corresponded to a chemical shift of the $\mathrm{H}-11$ and $\mathrm{H}-7,9$ positions, demonstrating the formation of a quaternized structure. The peaks of C-4, C-1, C-5, C-3, and C-2 and C-6 corresponded to the signals at chemical shifts of $97.46 \mathrm{ppm}, 76.31 \mathrm{ppm}, 74.75 \mathrm{ppm}, 70.01$ 
ppm, and $60.01 \mathrm{ppm}\left({ }^{13} \mathrm{C}\right)$, respectively. The peaks at $\delta=55.80$ and $\delta=50.32$ were the signals of C-7 and C-9 and C-8 and C-10, respectively. These results of FTIR and NMR showed that NSQC was successfully synthesized according to the synthetic route.

\section{Analysis of Films' Morphology, Thermal Stability, and Mechanical Properties}

The appearance, color, and transparency of the QCC film prepared by mixing cellulose with NSQC did not change compared with RC film. The 5000× magnified view of the RC film surface was compact and smooth, while a uniformly dispersed granular structure appeared at the surface of the QCC4 film (Fig. 4a and 4b). This was likely because NSQC accumulated on the surface of the cellulose film, resulting in the appearance of granular NSQC on the surface of the film.

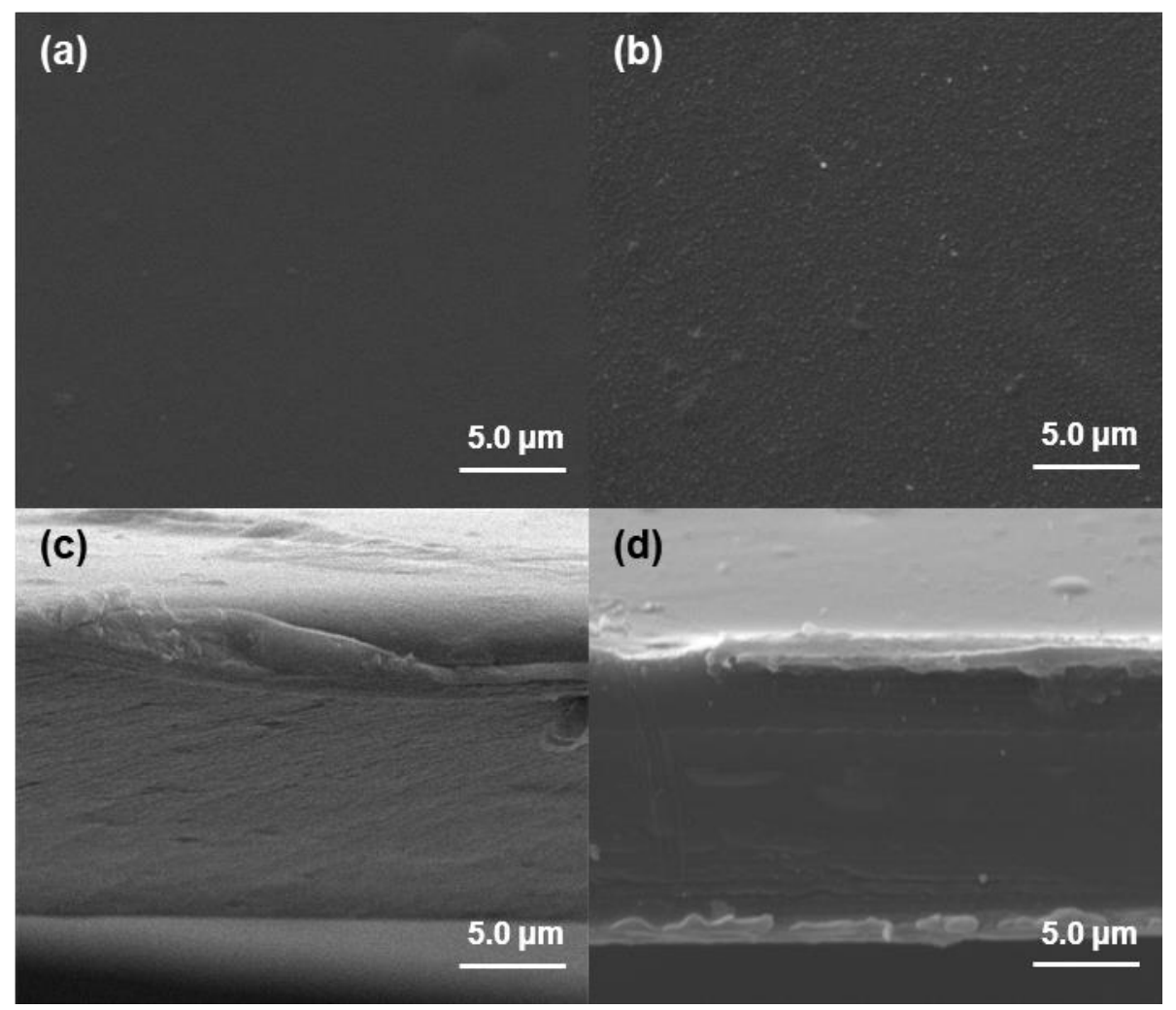

Fig. 3. SEM images of RC film and QCC4 film: (a) The surface picture of RC film; (b) The surface picture of QCC film; (c) The cross-section picture of RC film; and (d) The cross-section picture of QCC film

The surface elemental composition of RC and QCC4 films in Fig. 4a and 4b, as shown in Table 1, were obtained by EDAX scanning. The content of Br in the QCC4 film surface was higher than that of the $\mathrm{RC}$ film. The composition of the $\mathrm{Br}$ atom increased from $0.13 \%$ to $1.48 \%$, and the mass percentage increased to $8.26 \%$, demonstrating that the granular structure of QCC4 film surface was composed of NSQC, which contained bromide. The cross-section of the cellulose film had a fibrous hierarchical structure and micropores, which disappeared after blending with NSQC (Fig. 4c and 4d). This may have been because NSQC acted as a filler to enhance the bonding ability of fiber, making it more densely bonded, causing the pores to disappear. 
Table 1. Composition of Wood Chips and Cellulose Samples

\begin{tabular}{|c|c|c|c|c|}
\hline Element & $\begin{array}{c}A t \% \text { of RC } \\
\text { Film }\end{array}$ & $\begin{array}{c}\text { Wt\% of RC } \\
\text { Film }\end{array}$ & $\begin{array}{c}\text { At\% of QCC4 } \\
\text { Film }\end{array}$ & $\begin{array}{c}\text { Wt\% of } \\
\text { QCC4 Film }\end{array}$ \\
\hline $\mathrm{C}$ & 60.11 & 54.04 & 56.61 & 47.41 \\
\hline $\mathrm{N}$ & 16.49 & 17.29 & 17.59 & 17.18 \\
\hline $\mathrm{O}$ & 23.27 & 27.89 & 24.32 & 27.15 \\
\hline $\mathrm{Br}$ & 0.13 & 0.78 & 1.48 & 8.26 \\
\hline
\end{tabular}

The QCC films prepared by the regenerated cellulose blending with NSQC displayed superior elasticity and bending performance compared with the RC film. The tensile strength of the films increased from $55 \mathrm{MPa}$ to approximately $65 \mathrm{MPa}$ and could reach up to $71.3 \mathrm{MPa}$, which were higher than chitosan/cellulose films published previously (Shih et al. 2009). The reason for this was the affinity of the NSQC and the fibers, which caused the fibers to combine more tightly during dissolution and regeneration procedures, as shown in the SEM image, thereby enhancing the tensile properties of the cellulose film. While the tensile strength of the QCC films showed the complex changes with the increase in content of NSQC, and the trend of elongation at break was similar. This indicated that excessive addition of NSQC undermined the uniformity of the film structure (as shown in the SEM images Fig. 4b and 4d), making it easier to form more stress concentration points during stretching, which caused mechanical properties of the film could not continuously increase.

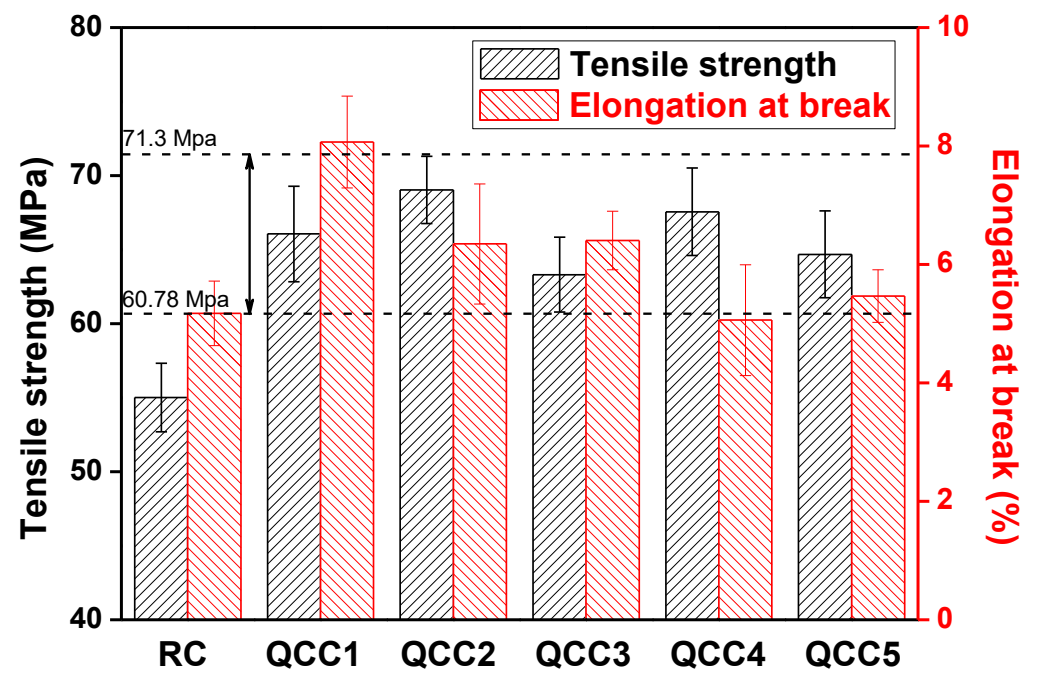

Fig. 4. Mechanical properties of RC film and QCC films

The reaction of cellulose combustion is divided into two stages: cellulose decomposition and char combustion (Gani and Naruse 2007). The thermogravimetric curve (TG) and a derivative thermogravimetric curve (DTG) curve of RC and QCC4 films are shown in Fig. 6. The mass loss of RC and QCC4 film at temperatures lower than $200{ }^{\circ} \mathrm{C}$ was mainly due to fiber pyrolysis, and the hydrogen bond broke to form carbonyl, carboxyl, and peroxide. The radicals reacted with oxygen to form $\mathrm{CO}, \mathrm{CO}_{2}$, and $\mathrm{H}_{2} \mathrm{O}$, accompanied with char residue. The combustion of fiber at approximately $300{ }^{\circ} \mathrm{C}$ released a large amount of heat, which further accelerated pyrolysis and combustion, and resulted in rapid mass loss in the films. The reaction formed gas and a small amount of relatively stable coke. The 
continuous increase of temperature promoted complete combustion of the remaining coke. The mass of residue was less than $1 \%$ at $750{ }^{\circ} \mathrm{C}$. The TGA showed that the mass loss of QCC4 film was lower than the RC film at the same temperature. The peak intensity of the QCC film at $300{ }^{\circ} \mathrm{C}$ in DTG was weaker. These results suggested that the added NSQC could be combined with cellulose to form a more stable structure, which would reduce the combustion rate of fiber decomposition and thus improve the thermal stability of the cellulose film.

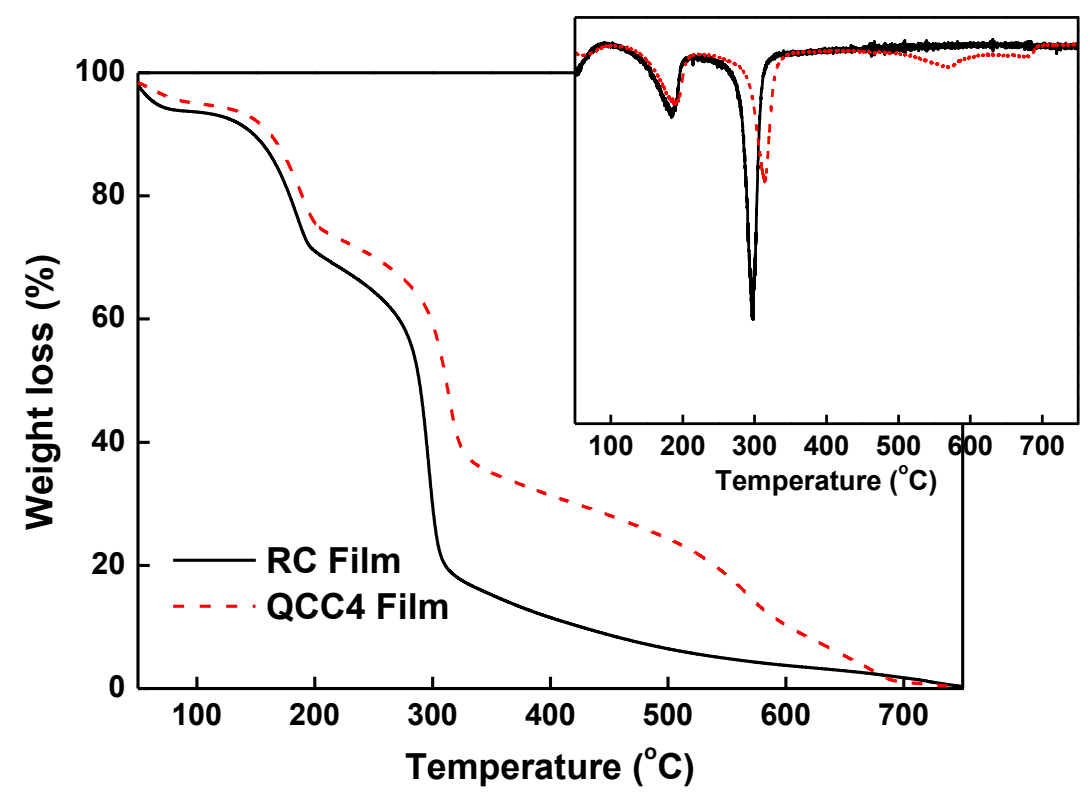

Fig. 5. TG curves of RC film and QCC4 film; the inset shows the DTG curves

\section{Analysis of NSQC and Films' Antibacterial Activity}

The method of NSQC sterilization can be attributed to the "adsorption-penetrationdestruction" type. Positively charged quaternary groups adsorbed and combined with the negatively charged cell wall peptidoglycan layer of bacteria to make it lose its effect. Therefore, the antibacterial substance continued to destroy the interior structure of bacteria, leading to the leakage of DNA, $\mathrm{K}^{+}$of the cells, and resulting in bacterial necrosis (Walsh et al. 2003; Vieira and Carmona-Ribeiro 2006; Asri et al. 2014). The MIC values of E. coli and $S$. aureus were $1.28 \mathrm{mg} / \mathrm{mL}$ and $0.64 \mathrm{mg} / \mathrm{mL}$, respectively, based on the difference in $\mathrm{OD}_{600}$ values. This indicated that the low concentration of NSQC solution exhibited antibacterial activity. The antibacterial effect of NSQC solution against $S$. aureus was stronger than against $E$. coli, which could be attributed to the thickness of the cell wall peptidoglycan layer of Gram-positive bacteria being greater than that of Gram-negative bacteria (Kawahara et al. 2000). The bactericidal ratio of both kinds of bacteria was more than $95 \%$ after the NSQC concentration was increased from $1.28 \mathrm{mg} / \mathrm{mL}$ to $2.56 \mathrm{mg} / \mathrm{mL}$ (Fig. 7a, 7b, 7e, and 7f), indicating that $2.56 \mathrm{mg} / \mathrm{mL}$ was the MBC value for NSQC to protect against $E$. coli and $S$. aureus.

The inhibition zone pictures (Fig. 7i and 7j) showed that only QCC5 film had an inhibition zone against Escherichia coli. It was suggested that the NSQC dispersed in the QCC films had difficulty diffusing in the plate to form an antibacterial region. QCC5 film with 16\% NSQC content showed a similar inhibition zone compared with 40\% HTCC content carboxymethyl cellulose film published previously (Hu et al. 2016), which 
demonstrated that the QCC film unmistakably has antibacterial properties. The two kinds of bacteria incubated on the surface of the blank plate and RC membrane grew well in the NA plate (Fig. 7c, 7g, and 7d, 7h), while the bacteria incubated on the surface of the QCC4 film did not multiply (Fig. 7k and 7l), indicating that the sterilization method of the QCC films was mainly contact sterilization. The aggregation of NSQC on the surface of the QCC film made it easier for it to come in contact with the bacteria and digested its cell wall peptidoglycan layer. Therefore, the sterilization effect of QCC4 film against Gramnegative E. coli and Gram-positive S. aureus were both above $99.9 \%$.

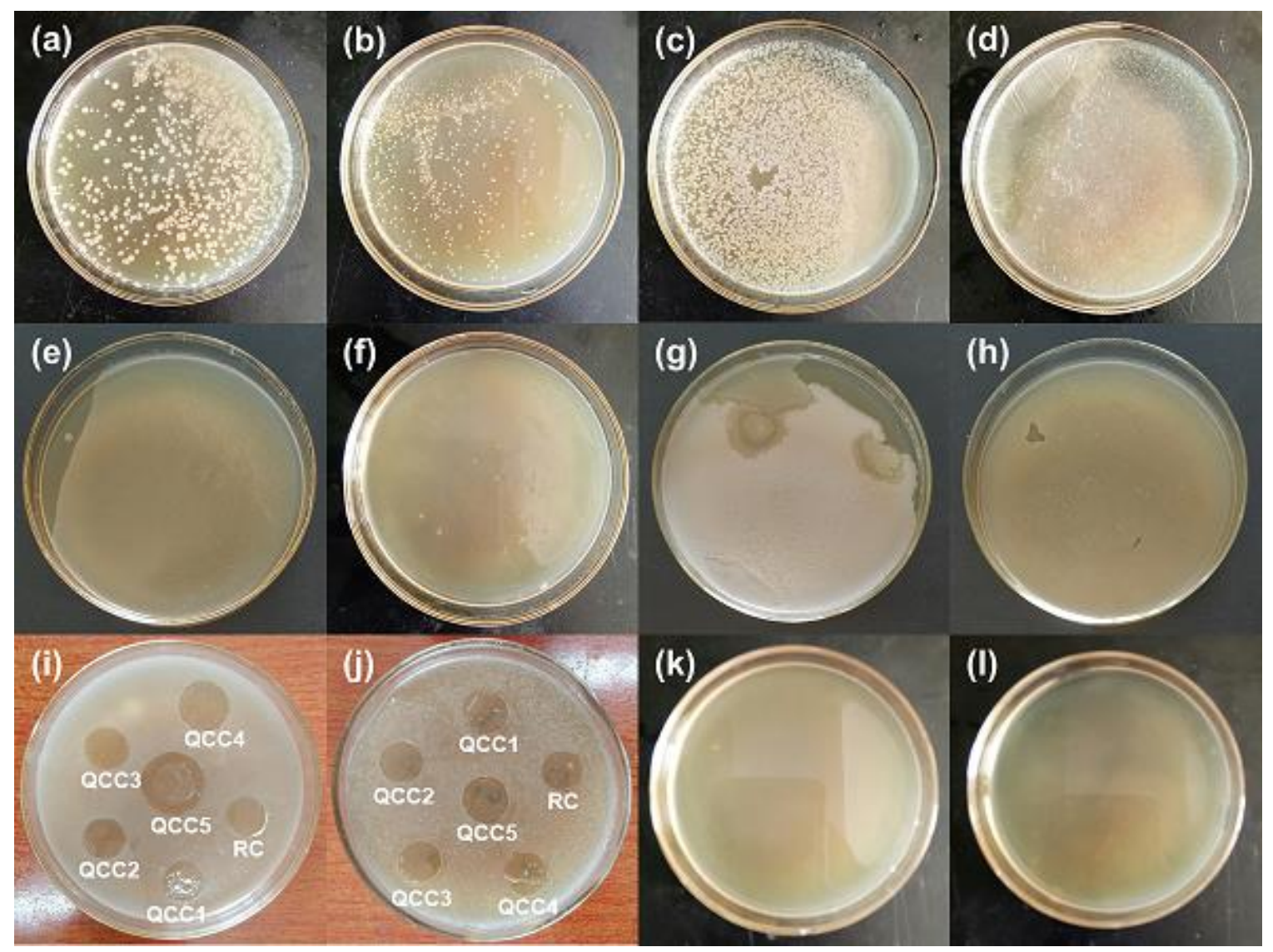

Fig. 6. The antibacterial activity of NSQC and QCC films: Respectively, (a), (e) The plates of 1.28 $\mathrm{mg} / \mathrm{mL}$ and $2.56 \mathrm{mg} / \mathrm{mL} \mathrm{NSQC} / E$. coli incubated for $48 \mathrm{~h}$; (b), (f) The plates of $1.28 \mathrm{mg} / \mathrm{mL}$ and $2.56 \mathrm{mg} / \mathrm{mL}$ NSQC/ S. aureus incubated for $48 \mathrm{~h}$; (i), (j) The pictures of films in $E$. coli and $S$. aureus plates incubated for $48 \mathrm{~h}$; (c), (g), (k) The pictures of blank control, RC film, and QCC4 films in E. coli plates incubated for $48 \mathrm{~h}$; and (d), (h), (l) The pictures of blank control, RC film, and QCC4 films in S. aureus plates incubated for $48 \mathrm{~h}$ 


\section{CONCLUSIONS}

1. Both FTIR and NMR characterizations confirmed that N-benzyl-N,N-diethyl was successfully synthesized by chitosan with water and organic solubility.

2. The cellulose was blended with NSQC to prepare quaternized chitosan-cellulose films. The affinity of the NSQC and the fibers made the fibers combine more tightly during dissolution and regeneration procedures, slowing down the pyrolysis combustion rate of cellulose and improving the thermal stability and tensile properties of cellulose film.

3. The aggregation of NSQC on the surface of the QCC film made it easier for it to come in contact with and destroy the bacteria. When the mass ratio of chitosan to cellulose was 8:100, the contact sterilization ability of composite film against $E$. coli and $S$. aureus exceeded $99.9 \%$.

4. The results showed that quaternized chitosan-cellulose films have potential application value in food packaging and bacterial barrier fields.

\section{ACKNOWLEDGEMENTS}

The authors are grateful for financial support from the Fundamental Research Funds for Central Universities (Grant No. 2572017AB22) for the research.

\section{REFERENCES CITED}

Abdul Khalid, H. P. S, Saurabh, C. K., Adnan, A. S., Nurul Fazita, M. R., Syakir, M. I., Davoudpour, Y., Rafatullah, M., Abdullah, C. K., Mohamad Haafiz, M. K., and Dungani, R. (2016). "A review on chitosan-cellulose blends and nanocellulose reinforced chitosan biocomposites: Properties and their applications," Carbohydrate Polymers 150, 216-226. DOI: 10.1016/j.carbpol.2016.05.028

Asri, L. A. T. W., Crismaru, M., Roest, S., Chen, Y., Ivashenko, O., Rudolf, P., Tiller, J. C., Van der Mei, H. C., Loontjens, T. J. A., and Busscher, H. J. (2014). "A shapeadaptive, antibacterial-coating of immobilized quaternary-ammonium compounds tethered on hyperbranched polyurea and its mechanism of action," Advanced Functional Materials 24(3), 346-355. DOI: 10.1002/adfm.201301686

Chang, A. K. T., Frias, Jr., R. R., Alvarez, L. V., Bigol, U. G., and Guzman, J. P. M. D. (2019). "Comparative antibacterial activity of commercial chitosan and chitosan extracted from Auricularia sp.," Biocatalysis and Agricultural Biotechnology 17, 189-195. DOI: 10.1016/j.bcab.2018.11.016

Chang, S. H., Lin, H. T. V., Wu, G. J., and Tsai, G. J. (2015). "pH effects on solubility, zeta potential, and correlation between antibacterial activity and molecular weight of chitosan," Carbohydrate Polymers 134, 74-81. DOI: 10.1016/j.carbpol.2015.07.072

Chen, Q., Xiao, S., Shi, S. Q., and Cai, L. (2018). "Isolation of cellulose from poplar wood by nitric acid-ethanol treatment and its effect on the quality of films cast from ionic liquid," BioResources 13(4), 8943-8955. DOI: 10.15376/biores.13.4.8943-8955

Chen, Y., Li, J., Li, Q., Shen, Y., Ge, Z., Zhang, W., and Chen, S. (2016). "Enhanced water-solubility, antibacterial activity and biocompatibility upon introducing 
sulfobetaine and quaternary ammonium to chitosan," Carbohydrate Polymers 143, 246-253. DOI: 10.1016/j.carbpol.2016.01.073

CLSI M07-A10 (2015). "Methods for dilution antimicrobial susceptibility tests for bacteria that grow aerobically," Clinical and Laboratory Standard Institute, Wayne, PA, USA.

CLSI M26-A (1999). "Methods for determining bactericidal activity of antimicrobial agents; approved guideline," Clinical and Laboratory Standard Institute, Wayne, PA, USA.

Crini, G. (2019). "Historical review on chitin and chitosan biopolymers," Environmental Chemistry Letters 1-21. DOI: 10.1007/s10311-019-00901-0

Fan, Z., Qin, Y., Liu, S., Xing, R., Yu, H., Chen, X., Li, K., and Li, P. (2018). "Synthesis, characterization, and antifungal evaluation of diethoxyphosphoryl polyaminoethyl chitosan derivatives," Carbohydrate Polymers 190, 1-11. DOI: 10.1016/j.carbpol.2018.02.056

Gan, I., and Chow, W. S. (2018). "Antimicrobial poly(lactic acid)/cellulose bionanocomposite for food packaging application: A review," Food Packaging and Shelf Life 17, 150-161. DOI: 10.1016/j.fpsl.2018.06.012

Gani, A., and Naruse, I. (2007). "Effect of cellulose and lignin content on pyrolysis and combustion characteristics for several types of biomass," Renewable Energy 32(4), 649-661. DOI: 10.1016/j.renene.2006.02.017

Ghazaie, M., Ghiaci, M., Soleimanian-Zad, S., and Behzadi-teshnizi, S. (2019). "Preparing natural biocomposites of N-quaternary chitosan with antibacterial activity to reduce consumption of antibacterial drugs," Journal of Hazardous Materials 371, 224-232. DOI: 10.1016/j.jhazmat.2019.03.003

Guo, Z., Xing, R., Liu, S., Zhong, Z., Ji, X., Wang, L., and Li, P. (2007). “Antifungal properties of Schiff bases of chitosan, N-substituted chitosan and quaternized chitosan," Carbohydrate Research 342(10), 1329-1332. DOI: 10.1016/j.carres.2007.04.006

$\mathrm{Hu}, \mathrm{D}$. , Wang, H., and Wang, L. (2016). "Physical properties and antibacterial activity of quaternized chitosan/carboxymethyl cellulose blend films," LWT - Food Science and Technology 65, 398-405. DOI: 10.1016/j.lwt.2015.08.033

ISO 1924-2 (2008). "Paper and board - Determination of tensile properties - Part 2: Constant rate of elongation method $(20 \mathrm{~mm} / \mathrm{min})$," International Organization for Standardization, Geneva, Switzerland.

ISO 22196 (2011). "Measurement of antibacterial activity on plastics surfaces and other non-porous surfaces," International Organization for Standardization, Geneva, Switzerland.

Jelkmann, M., Menzel, C., Baus, R. A., Ausserhofer, P., Baecker, D., Gust, R., and Bernkop-Schnürch, A. (2018). "Chitosan: The one and only? Aminated cellulose as an innovative option for primary amino groups containing polymers," Biomacromolecules 19(10), 4059-4067. DOI: 10.1021/acs.biomac.8b01069

Jia, Z., Shen, D., and Xu, W. (2001). "Synthesis and antibacterial activities of quaternary ammonium salt of chitosan," Carbohydrate Research 333(1), 1-6. DOI: 10.1016/S0008-6215(01)00112-4

Kawahara, K., Tsuruda, K., Morishita, M., and Uchida, M. (2000). "Antibacterial effect of silver-zeolite on oral bacteria under anaerobic conditions," Dental Materials 16(6), 452-455. DOI: 10.1016/S0109-5641(00)00050-6 
Kumar, S., Deepak, V., Kumari, M., and Dutta, P. K. (2016). "Antibacterial activity of diisocyanate-modified chitosan for biomedical applications," International Journal of Biological Macromolecules 84, 349-353. DOI: 10.1016/j.ijbiomac.2015.12.027

Lee, M., Chen, B. Y., and Den, W. (2015). "Chitosan as a natural polymer for heterogeneous catalysts support: A short review on its applications," Applied Sciences 5(4), 1272-1283. DOI: 10.3390/app5041272

Li, K., Li, P., Cai, J., Xiao, S., Yang, H., and Li, A. (2016). "Efficient adsorption of both methyl orange and chromium from their aqueous mixtures using a quaternary ammonium salt modified chitosan magnetic composite adsorbent," Chemosphere 154, 310-318. DOI: 10.1016/j.chemosphere.2016.03.100

Liu, N., Chen, X. G., Park, H. J., Liu, C. G., Liu, C. S., Meng, X. H., and Yu, L. J. (2006). "Effect of MW and concentration of chitosan on antibacterial activity of Escherichia coli," Carbohydrate Polymers 64(1), 60-65. DOI:

10.1016/j.carbpol.2005.10.028

Martins, A. F., Facchi, S. P., Follmann, H. D. M., Pereira, A. G. B., Rubira, A. F., and Muniz, E. C. (2014). "Antimicrobial activity of chitosan derivatives containing Nquaternized moieties in its backbone: A review," International Journal of Molecular Sciences 15(11), 20800-20832. DOI: 10.3390/ijms151120800

Niu, X., Liu, Y., Song, Y., Han, J., and Pan, H. (2018). "Rosin modified cellulose nanofiber as a reinforcing and co-antimicrobial agents in polylactic acid/chitosan composite film for food packaging," Carbohydrate Polymers 183, 102-109. DOI: 10.1016/j.carbpol.2017.11.079

Rinaudo, M. (2006). "Chitin and chitosan: Properties and applications," Progress in Polymer Science 31(7), 603-632. DOI: 10.1016/j.progpolymsci.2006.06.001

Sadeghi, A. M. M., Dorkoosh, F. A., Avadi, M. R., Saadat, P., Rafiee-Tehrani, M., and Junginger, H. E. (2008). "Preparation, characterization and antibacterial activities of chitosan, N-trimethyl chitosan (TMC) and N-diethylmethyl chitosan (DEMC) nanoparticles loaded with insulin using both the ionotropic gelation and polyelectrolyte complexation methods," International Journal of Pharmaceutics 355(1-2), 299-306. DOI: 10.1016/j.ijpharm.2007.11.052

Sahariah, P., and Másson, M. (2017). "Antimicrobial chitosan and chitosan derivatives: A review of the structure-activity relationship," Biomacromolecules 18(11), 3846-3868. DOI: 10.1021/acs.biomac.7b01058

Shih, C.-M., Shieh, Y.-T., and Twu, Y.-K. (2009). "Preparation and characterization of cellulose/chitosan blend films," Carbohydrate Polymers 78(1), 169-174. DOI: 10.1016/j.carbpol.2009.04.031

Thakur, V. K., and Voicu, S. I. (2016). "Recent advances in cellulose and chitosan based membranes for water purification: A concise review," Carbohydrate Polymers 146, 148-165. DOI: 10.1016/j.carbpol.2016.03.030

Vieira, D. B., and Carmona-Ribeiro, A. M. (2006). "Cationic lipids and surfactants as antifungal agents: Mode of action," Journal of Antimicrobial Chemotherapy 58(4), 760-767. DOI: 10.1093/jac/dk1312

Walsh, S. E., Maillard, J.-Y., Russell, A. D., Catrenich, C. E., Charbonneau, D. L., and Bartolo, R. G. (2003). "Activity and mechanisms of action of selected biocidal agents on Gram-positive and -negative bacteria," Journal of Applied Microbiology 94(2), 240-247. DOI: 10.1046/j.1365-2672.2003.01825.x

Wang, C., Fan, J., Xu, R., Zhang, L., Zhong, S., Wang, W., and Yu, D. (2019). "Quaternary ammonium chitosan/polyvinyl alcohol composites prepared by 
electrospinning with high antibacterial properties and filtration efficiency," Journal of Materials Science 54(19), 12522-12532. DOI: 10.1007/s10853-019-03824-X

Wang, C.-H., Liu, W.-S., Sun, J.-F., Hou, G.-G., Chen, Q., Cong, W., and Zhao, F. (2016). "Non-toxic O-quaternized chitosan materials with better water solubility and antimicrobial function," International Journal of Biological Macromolecules 84, 418427. DOI: 10.1016/j.ijbiomac.2015.12.047

Wei, L., Tan, W., Wang, G., Li, Q., Dong, F., and Guo, Z. (2019). "The antioxidant and antifungal activity of chitosan derivatives bearing Schiff bases and quaternary ammonium salts," Carbohydrate Polymers 226, Article ID 115256. DOI: 10.1016/j.carbpol.2019.115256

Wei, Z., Xinlan, D., and Jinjie, Z. (2018). "Properties of cotton fabric modified with a chitosan quaternary ammonium salt nanoparticle," Fibres \& Textiles in Eastern Europe 26(4), 116-121. DOI: 10.5604/01.3001.0012.1322

Xu, T., Xin, M., Li, M., Huang, H., Zhou, S., and Liu, J. (2011). "Synthesis, characterization, and antibacterial activity of $N, O$-quaternary ammonium chitosan," Carbohydrate Research 346(15), 2445-2450. DOI: 10.1016/j.carres.2011.08.002

Zargar, V., Asghari, M., and Dashti, A. (2015). "A review on chitin and chitosan polymers: Structure, chemistry, solubility, derivatives, and applications," ChemBioEng Reviews 2(3), 204-226. DOI: 10.1002/cben.201400025

Zou, P., Yang, X., Wang, J., Li, Y., Yu, H., Zhang, Y., and Liu, G. (2016). “Advances in characterisation and biological activities of chitosan and chitosan oligosaccharides," Food Chemistry 190, 1174-1181. DOI: 10.1016/j.foodchem.2015.06.076

Article submitted: September 24, 2019; Peer review completed: November 17, 2019;

Revised version received: November 20, 2019; Accepted: November 22, 2019;

Published: November 26, 2019.

DOI: $10.15376 /$ biores.15.1.415-428 